\title{
UPAYA MENINGKATKAN DAYA SAING DI PASAR INTERNASIONAL PADA ERA GLOBALISASI (STUDI KASUS EKSPOR IMPOR DI INDONESIA)
}

\author{
Mega Safitri, Nuri Aslami \\ Universitas Islam Negeri (UIN) Sumatera Utara, Medan, Indonesia \\ Email: safitrimega994@gmail.com, nuriaslami@uinsu.ac.id
}

\begin{tabular}{|c|c|}
\hline NFO & STRAK \\
\hline & \multirow{9}{*}{$\begin{array}{l}\text { Bisnis Internasional adalah semua transaksi bisnis yang dilakukan antar } \\
\text { negara yang pelaksanaannya dilakukan oleh warga negara, perusahaan } \\
\text { ekspor - impor, maupun sebuah departemen pemerintah. Kegiatan bisnis } \\
\text { Internasional mempunyai spesifikasi karena melewati batas - batas } \\
\text { wilayah negara mempunyai aturan hukum, budaya, kebiasaan, bahasa, } \\
\text { mata uang yang saling berbeda. Dengan perbedaan - perbedaan ini maka } \\
\text { sebaiknya dalam kegiatan bisnis Internasional perlu hati - hati dalam } \\
\text { pelaksanaannya. }\end{array}$} \\
\hline & \\
\hline & \\
\hline & \\
\hline & \\
\hline & \\
\hline & \\
\hline & \\
\hline & \\
\hline & \\
\hline & transacti \\
\hline 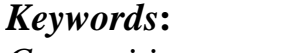 & tivities \\
\hline $\begin{array}{l}\text { ompetitiveness; } \\
\text { ternational }\end{array}$ & $\begin{array}{l}\text { ifications because they cross national boundaries and have } \\
\text { aws, cultures, customs, languages, and currencies. With these } \\
\text {, it is better for international business activities to be careful } \\
\text { plementation. }\end{array}$ \\
\hline
\end{tabular}

\section{Pendahuluan}

Perdagangan atau pertukaran adalah proses tukar menukar yang didasarkan atas kehendak sukarela dari masing-masing pihak yang melakukan transaksi sehingga tidak ada paksaan maupun ancaman dari pihak manapun (Triyono, 2008). Masing-masing pihak harus mempunyai kebebasan untuk menentukan keuntungan atau kerugian bagi kepentingannya dan masing - masing pihak menentukan akan melaksanakan pertukaran atau tidak.

Berdagang dengan negara lain karena ada motif keuntungan yang ingin diperoleh, membeli barang dan jasa dari negara asing karena dapat membeli dengan harga yang lebih murah, lebih bermutu, memenuhi selera konsumen atau belum dapat diproduksi di negaranya serta berbagai pertimbangan ekonomi lainnya (Sherly et al., 2020). Menjual ke negara lain misalnya karena dapat menjual dengan harga yang lebih mahal atau menjual barang yang tidak dapat diproduksi negara lain. Dengan menjual produk ke negara lain diperoleh keuntungan dari perluasan pasar serta meningkatkan produktifitas perusahaan.

Perbedaan harga produk atau komoditas ditentukan oleh perbedaan biaya produksi, suatu negara dapat efisiens dalam proses memproduksi sebuah produk atau komoditas sehingga dapat bersaing dipasar global. Oleh karena itu jenis barang yang diproduksi oleh suatu negara dengan negara lain akan berbeda dalam ongkos produksinya, perbedaan ongkos disebabkan karena perbedaan jumlah, jenis, kualitas, serta cara cara dalam mengkombinasikan faktor - faktor

$\begin{array}{ll}\text { How to cite: } & \text { Safitri, Mega, Nuri Aslami (2022). Upaya Meningkatkan Daya Saing Di Pasar Internasional Pada } \\ & \text { Era Globalisasi (Studi Kasus Ekspor Impor Di Indonesia), Action Research Literate, 6(1). } \\ \text { E-ISSN: } & 2721-2769 \\ \text { Published by: } & \text { Ridwan Institute }\end{array}$


produksi dalam proses produksinya. Perbedaan ini yang menyebabkan terjadinya perdagangan antar negara.

Perbedaan ongkos produksi bukan satu - satunya yang menyebabkan terjadinya perdagangan antar negara, namun masih terdapat banyak faktor yang mempengaruhinya, misalnya pada perbedaan dalam pendapatan dan selera.

Saat ini perdagangan antar negara dihadapkan pada berbagai tantangan terutama perkembangan yang sangat dinamis dalam hubungan perdagangan internasional. Peranan WTO dalam menegakkan sistem perdagangan multilateral yang akan menyebabkan tingkat persaingan yang semakin ketat di pasar global.

Asal barang menjadi kabur dengan semakin rumitnya produksi yang berasal dari banyak sumber dari berbagai negara, sehingga meningkatnya sistem produksi global, sumber- sumber daya industri bisa berasal dari dua negara atau lebih yang digabungkan menjadi barang setengah jadi yang dapat digunakan untuk konsumsi domestik maupun ekspor (AdriAn Sutedi, 2014).

Pengembangan daya saing produk pada suatu negara adalah transformasi keunggulan komparatif faktor pendukung yang relatif kuat menjadi keunggulan kompetitif produktif dan berdaya saing dipengaruhi faktor pendukung yang relatif kuat (Indraningsih, 2006). Upaya keunggulan kompetitif produk dengan menciptakan keunggulan produk sepanjang waktu melalui deferensiasi produk - produk dengan skala produksi yang efisien.

Menurut Michael E Porter dalam (Sahban \& SE, 2018) menyatakan bahwa keberhasilan suatu negara untuk meningkatkan keunggulan kompetitif suatu produk industri sangat dipengaruhi oleh empat faktor utama yang saling terkait yaitu posisi faktor produksi seperti tenaga ahli atau infrastruktur yang diperlukan sifat dan kondisi permintaan dalam negeri terhadap barang dan jasa yang dihasilkan, keterkaitan antara industri dalam negeri yang dapat mendukung pasokan barang/jasa yang kompetitif, kebijakan nasional yang terintegrasi dalam strategi usaha serta pengambangan struktur industri dan kondisi persaingan yang ada di dalam negeri.

\section{Metode Penelitian}

Penelitian ini menggunakan metode deskriptif analitis (Gunawan, 2013), yaitu suatu metode yang mendeskripsikan hasil analisis masalah guna menjawab permasalahan penelitian. Dalam hal ini, menganalisis upaya meningkatkan daya saing di pasar internasional pada era globalisasi studi kasus ekspor impor di Indonesia. Hasil yang didapat dari penelitian ini adalah upaya meningkatkan daya saing di pasar internasional pada era globalisasi studi kasus ekspor impor di Indonesia.

Perolehan data dilakukan melalui metode riset kepustakaan (library research) (Sari \& Asmendri, 2020). Data sekunder bersumber dari berbagai informasi yang diperoleh dari media internet terkait dengan ekspor impor di Indonesia. Kemudian, data diramu dengan kajian pustaka Bisnis internasional sehingga didapatkan sebuah kajian ilmiah untuk mendapatkan sebuah model dalam upaya meningkatkan daya saing di pasar internasional pada era globalisasi studi kasus ekspor impor di Indonesia.

\section{Hasil dan Pembahasan}

A. Organisasi Internasional Dalam Globalisasi

Pada tahun 1990 istilah globalisasi terasa asing, namun sepuluh tahun kemudian istilah globalisasi sering muncul pada setiap perbincangan. Globalisasi dapat dipahami sebagai sebuah nama "meliputi seluruh tempat di dunia".

Upaya untuk melakukan pembebasan perdagangan dapat dilakukan dengan melalui pendekatan internasional 
dan regional. Pendekatan internasional seperti apa yang dilakukan dalam WTO, yang bertujuan untuk mengurangi rintangan baik tarif maupun non tarif.

Dalam (Situngkir, 2018) Perjanjian multilateral sebagai sebuah perjanjian internasional yang melibatkan tiga negara atau lebih peserta, biasanya perjanjian multilateral berisi kesepakatan bersama dimulainya dan berakhirnya suatu perjanjian, dan hal - hal khusus yang dirinci dalam perjanjian tersebut. Bagi negara - negara yang ingin mengikat perjanjian dengan salah satu negara yang terikat dalam perjanjian multilateral, maka secara otomatis perjanjian itu berlaku terhadap negara tersebut.

Perjanjian regional adalah perjanjian antara beberapa negara dalam kawasan atau region ekonomi tertentu, biasanya membuat kesepakatan untuk melakukan kerjasama dibidang politik, ekonomi, sosial, budaya dan pertahanan (Widyasanti, 2010). Regional artinya kawasan (negara atau daerah) dengan cakupan geografis tertentu yang saling berpengaruh dan memiliki hubungan satu dengan lainnya.

Pendekatan regional menyangkut kerjasama antara beberapa negara dengan tujuan melakukan perdagangan bebas diantara negara anggotanya, tetapi tetap melakukan rintangan terhadap negara yang bukan anggota ( yang tidak mengikuti perjanjian regional). Bentuk kerjasama ini antara lain FTA, pasar bersama (common markets) dan Kesatuan Pabean (Customs Unions).

FTA merupakan suatu wilayah tertentu yang terdiri dari dua atau lebih dimana negara- negara tersebut secara bersama - sama membuat perjanjian yang bertujuan menghilangkan hambatan baik yang sifatnya tarif maupun non tarif khusunya di wilayah mereka sendiri.
Negara anggota FTA tidak secara seragam menantukan kebijaksanaan ekonomi serta tarif terhadap barang yang masuk dari negara bukan anggota (Ayu, 2013).

1. Serikat kepabeanan (Custom Union) mengandung unsur perdagangan bebas serta unsur pioteksi yang lebih besar, negara anggota menambahkan suatu tarif eksternal bersama pada bentuk FTA sedangkan negara anggota telah menghapus tarif diantara mereka sendiri.

2. Pasar bersama (common markets) adalah serikat kepabeanan ditambah dengan penghapusan retriksi tentang mobilitas modal dan tenaga kerja diantara negara - negara anggota.

3. Merupakan bentuk intergrasi ekonomi dengan tingkat integrasi politik yang tinggi karena negara - negara anggota menyerahkan unsur kedaulatan yang penting. Termasuk didalamnya penggantian mata uang anggota dengan mata uang tunggal.

4. Pasar tunggal eropa, bertujuan untuk menciptakan pasar dimana industri ME dapat bersaing dalam suatu kondisi yang sama. Pasar tunggal eropa akan menjadi pasar serba lengkap, dimana barang - barang akan beredar dengan bebas dibawah kondisi persaingan tanpa distorsi bagi perorangan maupun perusahaan tanpa memperhatikan dimana kedudukan mereka di ME. Hal ini dapat dicapai dengan menghapus semua hambatan artifisial terhadap perdagangan antar negara anggota.

Pada saat ME didirikan pada tahun 1957 yang apada awalnya hanya enam negara anggota, terdapat berbagai kendala yang menghambat proses pembentukan pasar bersama yang tunggal, menyangkut bea masuk, kuota ekspor-impor, pengawasan imigrasi bagi perpindahan penduduk, pengawasan moneter terhadap 
arus keuangan antara negara anggota dan pembatasan undang - undang pendirian perusahaan. Pakta Roma telah mencakup dasar- dasar penetapan undang - undang yang dimaksudkan untuk menghapuskan rintangan semacam itu.

\section{Kesatuan Pabean Eropa}

(Community Customs Union) segera di bentuk, seluruh bea masuk dan pembatasan kuantitatif serta semua biayabiaya dan aturan-aturan lain yang memiliki pengaruhnya sama terhadap impor dan ekspor antara negara anggota dihapuskan. Sebagai gantinya diciptakan Tarif Pabean yang seragam (Common Customs Tariff), dimana seluruh barang impor dari negara bukan anggota dikenakan tingkat tarif dan pungutan yang sama.

Walaupum ME adalah suatu Custom Union (Kesatuan pabean) yang memiliki Common Custom Tariff (Keseragaman tarif bea masuk) dan Common commercial policy (Keseragaman dalam kebijaksanaan komersial), namun pada kenyataannya sampai saat ini penerapan common customs regime belum dapat dilakukan sepenuhnya. Oleh karena itu ME masih terus bergerak kearah standarisasi prosedur pabean di ke-12 negara anggotanya.

Impor di ME disamping diperlukan ketentuan ME dan prosedurnya, tetapi juga undang- undang nasional negara bersangkutan yang masih berlaku dan berbeda antara satu negara anggota dengan yang lainnya. Kedua perangkat ketentuan yang dimaksud diterapkan pada tempat pemasukan (point of entry). Impor di ME terdiri dari dua tingkatan prosedur yang terpisah yaitu pernyataan terhadap barang (declaring goods) dan penyelesaian pabean (Clearing customs). Apabila kedua tingkat tersebut telah dapat diselesaikan maka barang impor tersebut tinggal memenuhi prosedur transit di ME.
Pernyataan terhadap barang menyangkut suatu barang yang masuk ke ME, maka importir yang bersangkutan atau individu yang bertanggung jawab terhadap barang dimaksud harus mengajukan permohonan kepada pihak pabean yang berwenang dan membuat suatu Summary Declaration. Dalam hal tertentu bisa saja seorang importir mengimport untuk keperluan pasar Jerman melalui perancis untuk kemudian diteruskan ke Jerman.

Penyelesaian kepabeanan dilakukan oleh pabean yang berwenang dinegara anggota dimana barang diimpor bertanggung jawab dalam menentukan nilai barang dengan tepat guna keperluan penilaian bea. Proses dalam penilaian melibatkan 3 langkah, yaitu klasifikasi barang (classifying goods), penilaian barang (valueing goods) dan penetapan bea masuk (determination and payment of duties).

Dalam Classification of Goods seluruh anggota ME memiliki suatu standar format untuk mengklasifikasikan impor ke dalam MEE yang disebut Combined Nomenclatur yang diadministrasikan oleh the Customs Coorperation Council (CCC) berdasarkan Nomenclatur Harmonized Tariff Sustem (HTS). Barang - barang diklasifikasikan oleh pabean masing - masing negara anggota (national customs authorities) dengan mengikuti pedoman dari HTS.

\section{B. Bisnis Ekspor Dan Impor}

Perusahaan yang akan mengawali ekspor biasanya memulai dari mencari pembeli di luar negeri. Untuk mencari pembeli di luar negeri ada beberapa cara yaitu; dengan mengikuti pameran dagang baik di dalam negeri maupun diluar negeri, keikutsertaan dalam misi dagang, melalui kantor kedutaan besar di luar negeri yaitu atse perdagangan maupun ITPC (Indonesia Trade Promotion Centre) 
maupun perwakilan negara asing di dalam negeri, melalui Departemen Perindustrian dan Perdagangan, melalui Dinas Perindustrian dan Perdagangan di tingkat propinsi maupun kabupaten/kota. Setelah memperoleh nama dan alamat calon pembeli di luar negeri, maka dapat dilakukan hubungan korespondensi baik dengan surat maupun media elektronika.

Kombinasi-kombinasi faktor-faktor produksi membuka perdagangan ekspor, yang tidak lain berkaitan dengan keunggulan komperatifnya. Badan usaha perdagangan (trader) dapat melakukan kegiatan ekspor melalui pengumpulan produk yang dibuat oleh industri kecil maupun industri berskala rumah tangga yang, belum mampu ekspor dari segi manajemennya, melalui pola pembelian langsung maupun kemitraan usaha. Badan usaha Ira melakukan ekspor karena kemampuannya secara administrasi serta akses pasar yang dimilikinya di luar negeri, kadang bahan usaha perdagangan telah memiliki perwakilannnya di luar negeri.

Impor adalah kegiatan memasukkan barang ke dalam daerah pabean yaitu suatu wilayah Republik Indonesia yang meliputi darat, perairan dan ruang udara diatasnya serta tempat-tempat tertentu dt Zona Ekonomi Eksklusif dan landas kontinen yang didalamnya berlaku Undang-Undang nomor 10 tahun 1995 tentang Kepabeanan.

Kebijakan impor yang diberlakukan di Indonesia dalam pelaksanaanya mengacu pada undang-undang nomor 7 tahun 1994 tentang Pengesahan Persetujuan Pembentukan Organisasi Perdagangan Dunia (WTO) yang memuat rambu-rambu yang wajib dipatuhi oleh setiap negara anggota WTO.

Impor dapat dilakukan oleh perusahaan yang telah memiliki Angka Pengenal Impor API). API terdiri dari API Umum (AP1- U) yang diberikan pada perusahaan dagang, pemilik API-U dapat mengimpor barang dengan tujuan untuk diperdagangkan dan jenis barang yang dapat diimpor adalah barang - barang yang tidak diatur tata niaga impornya. API Produsen (API-P) diberikan kepada perusahaan industri diluar PMA/PMDN, API-P hanya dapat dipergunakan untuk mengimpor barang tertentu untuk keperluan proses produksi pepasahaan pemilik API-P.

Perdagangan ekspor dan impor adalah perdagangan menggunakan dokumen, artinya hampir seluruh kegiatannya dilaksanakan memakai dokumen. Kemampuan administrasi dalam menangani dokumen ekspor-impor pada setiap perusahaan perlu diperhatikan, karena sedikit saja kesalahan pada dokumen ekspor kadang menimbulkan masalah.

Dalam melaksanakan kegiatan bisnis internasional perlu diketahui cara pembayaran ekspor serta cara penyerahan barang ekspornya sesuai yang berlaku Umum dalam bisnis internasional.

C. Meningkatkan Transaksi Ekspor

1. Tahap promosi ekspor merupakan tahap awal seorang eksportir/calon eksportir memperkenalkan produk yang dihasilkannya kepada calon importir. Untuk melakukan promosi ekspor dapat ditempuh dengan cara, memasang iklan di media cetak maupun elektronika, melalui atase perdagangan maupun Indonesian Trade Promotion Centre (ITPC) negara kita di luar negeri, ikut serta dalam pameran dagang di luar negeri maupun di dalam negeri yang dikunjungi oleh calon importir, menggunakan jasa pemasaran internasional. Kegiatan pameran ekspor bertujuan agar calon importir mengenal, terkesan kemudian tertarik terhahadap produk yang kemudian mencoba untuk memasarkan 
dinegaranya. Calon importir biasanya membeli atau meminta contoh produk, hendaknya contoh produk yang dihasilkannya sesuai dengan hasil produk perusahaan yang sesungguhnya, sehingga pada saatnya importir memasarkan produknya sesuai mutu produk yang dipamerkan. Promosi bentuk lainnya misalnya dengan mengirim leaflet ke perwakilan dagang kita di luar negeri atau perwakilan dagang luar negeri yang berada di sini, atau dalam bentuk pembuatan CDRoom yang berisi spesifikasi produk dari mulai bahan baku, proses produksi, pengawasan mutu, serta kegiatan pengangkutan sampai di pelabuhan muat. Kegiatan promosi dapat pula dilakukan dengan menggunakan sarana internet. Adapula eksportir yang mengenal pembeli dari luar negeri dengan cara membuka gerai promosi di tempat yang sering dikunjungi oleh buyers misalnya hotel dan bandara. Kegiatan negosiasi sering dilakukan oleh eksportir dengan importir. Setelah eksportir mendapatkan pembeli dari luar negeri kemudian dilaksanakan kegiatan negosiasi.

2. Penerbitan Surat Permintaan Harga (Inquiry). Setelah melakukan melaukan promosi ekspor dan mendapatkan calon importir (buyers) yang berminat, maka calon importir akan menerbitkan Surat yang ditujukan kepada eksportir yang berisi permintaart harga (price) dart barang yang dipromosikan oleh eksportir. Surat Permintaan harga sering disebut sebagai letter of inquiry.

3. Penawaran Harga (Offersheet), setelah menerima letter of inquiry, maka eksportir melakukan persiapan kegiatan berupa perhitungan harga pokok dan harga jual yang dapat ditawarkan dalam bentuk valuta asing, cara pembayaran, kemampuan produksi dan sebaiknya menghubungi perusahaan pelayaran berkaitan dengan waktu pengapalannya. Setelah informasi lengkap, selanjutnya eksportir mengirim offersheet, offersheet berisi informasi selengkap-lengkapnya sehingga importir dapat mengambil keputusan atas produk yang ditawarkannya, antara lain berisi pernyataan kesanggupan eksportir untuk memasok produk kepada calon importir dengan syarat harga, waktu, penyerahan dan pembayaran yang ditentukan oleh penjual.

4. Penerbitan Surat Pesanan (ordersheet), Offersheet yang telah diterima oleh importir kemudian dipelajari secara cermat isi surat penawarannya satu persatu. Komunikasi dengan eksportir perlu dilakukan, syarat - syarat yang disetujui maupun tidak disetujui disampaikan kepada eksportir, termasuk perubahan - perubahannya. Setelah diteliti dan setuju atas offersheet yang diterbitkan, maka importir selanjutnya menuangkan bentuk persetujuannya dalam surat pesanan (ordersheet) atau dalam bisnis internsional dikenal dengan PO (Purchase Order).

D. Negosiasi Bisnis Internasional

Kegiatan Perdagangan internasional pada awalnya dapat dilakukan oleh eksportir dan importir melalui kegiatan negosiasi untuk memperoleh kesepakatan jual dan beli antara pihak-pihak yang bertransaksi tersebut.

Negosiasi adalah bentuk/sarana pertemuan antara dua pihak atau lebih dengan berbekal informasi melakukan perundingan/diskusi/tawar-menawar melalui adu argumentasi dalam rangka mencapai tujuan tertentu dengan menggunakan teknik, strategi dan caranya masing- masing namun berlandaskan pada 
itikat baik serta diupayakan dalam situasi yang terkendali.

Tujuan dari negosiasi adalah menyelaraskan misi/kepentingan pihak yang berunding sehingga akan dicapai hasil kesepakatan yang menguntungkan dan memuaskan semua pihak. Negosiasi adalah upaya untuk mempertemukan dua kepentingan yang saling berlawanan, atau bertentangan masing-masing pihak melakukan konsensi yaitu upaya untuk saling memberi dan memperoleh hak dari pihak lain.

Pelaksanaan kegiatan negosiasi dimulai dari membuat tim negosiasi yang anggotanya terdiri dari pihak-pihak yang berkompeten dalam bidangnya. Tahap pelaksanaan negosiasi dimulai dari :

1. persiapan,

2. pelaksanaan negosiasi berupa perkenalan pernyataan tujuan dan sasaran

3. penawaran

4. tawar menawar

5. kesepakatan/penyelesaian

6. pengesahan.

Tahap akhir dari negoasiasi adalah tahap penyelesaian atau kesepakatan dan pengesahan hasil negosiasi. Tahap penyelesaian sebaiknya berpedoman pada kriteria titik konsensi berada pada batas atas dan batas bawah, serta minat kita terpenuhi. Negosiasi dianggap sukses apabila

1. Kesepakatan yang dicapai harus lebih baik dari Alternatif terbaik yang kita miliki.

2. Kesepakatan yang dicapai memenuhi atau memuaskan kepentingan kita, tetapi dapat diterima lawan negosiasi dan bias ditolerir pihak lain.

3. Kesepakatan yang dipakai merupakan suatu yang terbaik dari semua opsi yang ada.

4. Kesepakatn yang dicapai dipatuhi oleh masing-masing pihak yang bernegosiasi karena hasilnya cukup adil, layak, dan dapat diterima dilihat dari criteria yang berlaku.

5. Kesepakatan yang dicapai berisikan komitmen yang benar-benar tercapai dengan baik, realistis dan bisa dilaksanakan.

6. Kesepakatan yang dicapai dihasilkan secara efisien melalui komunikasi yang efektif melalui komunikasi dua arah.

7. Kesepakatan yang dicapai bisa membantu terbentuknya hubungan kerja yang kerja yang baik antara sesama peserta negosiasi.

E. Pemasaran Internasional

Dalam kegiatan pemasaran internasional sering timbul pertanyaan: mengapa intensitas ekspor suatu negara ke negara lainnya sangat besar di lain hal ke negara lainnya sedikit? Tentunya ini berkaitan dengan permintaan pasar terhadap produk suatu negara.

Pasar dapat dikatakan sebagai suatu tempat atau daerah yang di dalamnya terdapat kekuatan permintaan dan penawaran yang saling bertemu untuk menentukan suatu harga. Terdapat tiga faktor yang menunjang, yaitu, orang dan segala keinginannya, daya beli, dan kemauan untuk membelanjakan uang. Potensi pasar ditentukan oleh tiga faktor utama yaitu struktur penduduk, daya beli, serta pola konsumsi masyarakat di suatu negara.

Untuk memasuki pasar baru, maka pelaksana ekspor dapat mempertimbangkan data- data mengenai GNP perkapita suatu negara, serta kondisi perekonomian negara yang produknya akan dipasarkan dengan pertumbuhan ekonominya yang cukup cepat.

Penyaringan pasar adalah metode analisis dan penilaian pasar yang memungkinkan manajemen 
mengidentifikasi pasar-pasar yang diinginkan dengan menggunakan pengamatan-pengamatan lingkungan. Langkah-langkah penyaringan pasar dilakukan

1. Pengamatan Perdagangan dan investasi Luar Negeri

2. Pengamatan Kekuatan-kekuatan ekonomi dan keuangan

3. Pengamatan Kekuatan-kekuatan politik dan hukum

4. Pengamatan Kekuatan-kekuatan sosiokultural

5. Pengamatan Kekuatan-kekuatan kompetitif

6. Kunjungan-kunjungan oleh manajemen

\section{Kesimpulan}

Terwujudnya perdagangan bebas cenderung untuk mendorong masing-masing negara untuk berspesialisasi secara penuh dalam produksi barang yang mempunyai keunggulan komperatif bagi negara tersebut. Kesiapan suatu negara dalam globalisasi tergantung bagaimana cara negara tersebut mendorong produk yang dihasilkannya mempunyai keunggulan komparatif. Dengan keunggulan komperatif akan dihasilkan produk yang berdaya saing di pasar global.

Selain itu, dengan tumbuhnya kawasan-kawasan perdagangan dunia, yang cenderung membentuk blok-blok perdagangan hampir disemua benua, menambah globalisasi perdagangan di dunia saat ini.

Globalisasi ekonomi adalah perluasan pasar global dimana sumber-sumber daya global pada produksi dan pemasaran tidak dibatasi lagi oleh batas geografis negara. Sesungguhnya globalisasi mencakup bidang yang lebih luas, termasuk didalamnya pengaruh bidang politik, teknologi dan budaya.

Peran pasar menjadi lebih penting dalam menciptakan kondisi ekonomi daripada pemerintah. Negara dapat memiliki suatu cara yang dianggap paling sesuai, tetapi kebijakan pasarlah yang akan berkaitan langsung dengan pasar global. Perusahaan-perusahaan dan bentuk organisasi lainnya tidak lagi dibatasi oleh wilayah nasional, dunia benarbenar telah menjadi satu "desa" global.

\section{BIBLIOGRAFI}

AdriAn Sutedi, S. H. (2014). Hukum Ekspor Impor. RAS.Google Scholar

Ayu, Y. F. (2013). Dampak Kesepakatan Asean China Free Trade Area (ACFTA) Terhadap Sektor Pertanian di Lima Negara Asean Yosika Falista Ayu F1111037. Google Scholar

Gunawan, I. (2013). Metode penelitian kualitatif. Jakarta: Bumi Aksara, 143. Google Scholar

Indraningsih, K. S. (2006). Mewujudkan keunggulan komparatif menjadi keunggulan kompetitif melalui pengembangan kemitraan usaha hortikultura. Google Scholar

Sahban, M. A., \& SE, M. M. (2018). Kolaborasi Pembangunan Ekonomi di Negara Berkembang (Vol. 1). Sah Media. Google Scholar

Sari, M., \& Asmendri, A. (2020). Penelitian Kepustakaan (Library Research) dalam Penelitian Pendidikan IPA. Natural Science: Jurnal Penelitian Bidang IPA Dan Pendidikan IPA, 6(1), 41-53. Google Scholar

Sherly, S., Halim, F., Butarbutar, M., Arfandi, S. N., Sisca, S., Purba, B., Ferinia, R., Dewi, I. K., Hasyim, H., \& Sudarso, A. (2020). Pemasaran Internasional. Yayasan Kita Menulis. Google Scholar

Situngkir, D. A. (2018). Terikatnya Negara Dalam Perjanjian Internasional. Refleksi Hukum: Jurnal Ilmu Hukum, 2(2), 167180. Google Scholar 
Triyono, T. (2008). Upaya Meningkatkan Daya Saing di Pasar Internasional pada Era Globalisasi. Value Added: Majalah Ekonomi Dan Bisnis, 4(2), 22812. Google Scholar
Regional dan Daya Saing Ekspor: Kasus Indonesia. Buletin Ekonomi Moneter Dan Perbankan, 13(1), 5-22. Google Scholar

Widyasanti, A. A. (2010). Perdagangan Bebas

\section{Copyright holder :}

Mega Safitri, Nuri Aslami (2022).

First publication right :

Action Research Literate

This article is licensed under:

(c) (i) (?) 